\title{
IMPORTANCE OF HUMAN RESOURCES TO SOCIAL DEVELOPMENT
}

\author{
Venelin Terziev \\ Corresponding Member of the Russian Academy of Natural History, Moscow, Russia, Prof. \\ D.Sc. (Ec.), D.Sc. (National Security), D.Sc. (Social Activities), Ph.D., National Military University, \\ Veliko Tarnovo, Bulgaria; University of Rousse, Rousse, Bulgaria, terziev@skmat.com
}

\begin{abstract}
The importance of social policies and human resources for social development is a question of special consideration in contemporary globalizing society suffering a number of problems in its social and economic development. Current study makes analyses of the key features of the human resources and the importance of social activity outlining the main factors triggering the change and proposing the application of the model of "collective qualification". The conclusion focuses on the social system management requirements born by the environment and the need to "release” the unrevealed potentials of human resource.
\end{abstract}

Keywords: human resources, management, social policy.

\section{INTRODUCTION}

The key factor for socio - economic development is people. They are the foundation of social management as a separate managerial area, the goal of which is the management of the interaction between the subject and the object, (having their social character), occurring in a particular social environment. To what degree the actions of the subject and the object, as elements of social management are adequate to the changes in the environment, is determined by their activity. Moreover, the rationalization of social managerial decisions is directly dependent on the social policy carried out.

The social policy - as a set of principles, legal norms, institutions and activities, aimed at creating conditions ensuring the quality of life of the citizens of a country, is an expression of the social relations between the state and its citizens. The social policy determines the safety (social, health, economic) and security of the people in the socium. This is why it is defined as „philosophy, ideology, program for influence on the demographic situation, employment of the population, level, way and quality of living of the population, „its income level and structure of consumption of material and cultural wealth,... forms of social security, social services to the population, ... providing targeted state aid to the most unprotected, the most vulnerable and poor layers of the population,... measures aimed at creating conditions for self-defense in order to maintain and improve the level of well-being...".

It is noteworthy that within the scope of social policy a wide arsenal of concepts is included (social protection, social safety, social support, social self-protection, quality of life), defined in the quoted edition. From here, in the content of social policy are differentiated concrete actions of the state bodies, non-state institutions, and 
public associations, related to the implementation of tactical and strategic objectives for the harmonization of public relations. Since the foundation of these relations is the people with their actions and skills, they are a crucial factor of social policy. Inside there are synthesized and multiplied the other components of a country's resources and thus they are transformed into a finished product in the planning of the goals for achieving socio-economic development, making it possible to carry out an effective social policy.

Moreover, researches show that $70 \%$ of the world's wealth is in the form of human capital - the skills and knowledge of the people and not in physical or financial capital. The strategy of many companies today is clearly guided by the idea of human resources, stressing on individualization, service and innovation.

Put another way, human resources are the people in an organization which, by their professional and personal qualities, make it possible to achieve its strategic objectives. Together with the rest of the resources, they should meet the needs of the organization, and the way they are transformed into abilities, predetermines the efficiency of their use. This means that they, human resources, together with others, become a function, a subsystem and an object of management. The reason for this is the circumstance that in terms of goal setting, they are a function of management. The application of the accumulated scientific knowledge on the general theory of systems, basing on the system approach, interacting with other management subsystems, characterizes them as a management subsystem. Through the forward and backward informational feedback, they are a subject to management, influence for the purpose of obtaining certain result. Therefore, human resource management (HRM) is defined as „a system of principles, methods, tools, legal norms, rules, criteria, requirements, standards, procedures, policies, plans and programs of formation and use of human resources in the organization, in accordance with its immediate interests and strategic objectives".

In other words, HRM is an activity resulting from the strategic objectives of the organization, which requires the implementation of a strategic management approach in taking managerial decisions, related to this resource. In this sense, the human resources are a reflection of specific social relations in the interests of social governance, as part of a nationwide management. And in an environment of dynamic changes, requiring the participation of human resources in the socio-economic processes, by maintaining and developing adequate to the changes in the social environment abilities to harmonize social relations, there are demands on establishment of an effective system of social activity, which is also the goal of the study presented in this publication.

\section{DETAILS EXPERIMENTAL}

\section{Social activity as a factor of change in public relations}

The social activity is inherently associated with foresight and proactive actions. Put another way, it is directly related to the change in social relations caused by people, by the individual. From here, ,...social activity is the realization of a particular new norm-measure of the activity, which norm-measure stands out as new in direct comparison with the established one, with that which is considered "normal” by common sense in life. The individual realizes this new norm-measure either in his/her own activities or in the activities of other people, their associations, public institutions activity that generates activity".

What is noteworthy is that the essential characteristics of social activity are the change, the activities, the social subject, the public system, the public relations.

In all his/her actions, ,the individual intentionally makes changes in the activity and its results (his/her or someone else's activity) and thus causes social change and creates conditions for change (progressive or regressive)".

Social activity is objectively and subjectively conceptualized by the individual as his/her activity for the development of society from the position of the adopted by him/her specific team interests, ideals and ideas. Social activity is (1) a purposeful effort on the part of the individual (2) for a significant personal contribution to this development, (3) through the available forms and means (4) to the possible extent. And this determines his/her public predestination, the expression of which is the alignment of the social system and public relations with the dynamic changes in the social environment.

Since, in the basis of these projections and activities stays the subject, the human resource, led by the private and public interest towards change, the social activity is associated with the concept of the term interest, motivation, desire for satisfaction of needs that depend on organizational changes, the intensity of these activities is directly dependent on the factors of the social environment. All this resides within the scope of social management as part of the general managerial process and in connection with the management of human resources. In order to have efficient management of social processes, it is more than ever necessary to observe certain rules, principles which in scenes are also principles of the human 
resources management (HRM). This concerns the following:

- Predictability, expression of which is in synchronizing social management with the longterm strategic requirements and social needs;

- Integration, the relevance of which is in the integration of social management in a unified framework, which to consolidate the planned strategic goals of social policy on the basis of fair treatment of the individual;

- Synchronization, expressed in planning, organizing, coordinating the activities in social management;

- Protection of information, consistent with the requirements for personal data protection, integrity and security of information, related to the individual and the social processes;

- Empathy, guaranteeing the identification of the needs of the individual and their satisfaction in a real social environment;

- Flexibility on the basis of which social management to adapt to changes in the social environment.

And all this is in the interest of the objectives and tasks of social policy, the achievement of which is a result of the activity of the human factor, understood as an individual, a team, the society, and the relations between the people in this team, in this society on the basis of self-awareness. And this activity, social in its nature, is determined by certain factors- general and specific.

Amongst the general factors of social activity, special attention deserve:

- The common culture, which is important for the behavior of the human factor in the team, in the society;

- The special-functional culture resulting from the behavior of the individual in the realization of professional relationships;

- The motivating factors relating to the stimulation and consideration of interests of individuals in the team and in the society.

The specific factors of social activity include:

- The way of taking management decisions, while leading are these two moments - one, when it is necessary to ensure the participation of the team, the society in the execution of the decision, and the second, when it is important to act immediately and in a short time to achieve the intended purpose;

- The way of managerial communication, while extremely important is the managerial responsibility, manifested by the so called „Ruling Five”, illustrated by the fingers of the hand.

Through this approach the following questions receive their answers: greater pressure (the thumb); who is to blame (the index finger); whose is the choice (the middle finger); whose are the instructions (the ring finger) and who is in control (the little finger).

The application of this approach to managerial communication is essential in the implementation of managerial decisions in the social sphere, which too often should be taken depending upon the particular situation and the implementation of which is a result of the contribution of each member of the team, of the society and their team wise interaction.

Achieving motivation in the individual sometimes determines the practice the answer to the questions of the Ruling Five to be given „face to face” (Terziev, Georgiev, 2017, pp. 94-101; Terziev, Georgiev, 2017a, pp. 1418-1437; Terziev, Georgiev, 2017b, pp. 602-606; Terziev, Georgiev, 2017c, pp. 607-610; Terziev, Banabakova, Ilsheva, Georgiev, 2017d, pp. 44-53; Terziev, Banabakova, Ilsheva, Georgiev, 2017e, pp. 138145; Terziev, Banabakova, Georgiev, 2017f, s.64-69; Terziev, Banabakova, Georgiev, 2017g, s.70-75; Terziev, Banabakova, Georgiev, 2017h, s.76-81; Terziev, Banabakova. Georgiev, 2017i, s. 103-106; Terziev, Banabakova., Georgiev, 2017j, s. 100-103; Terziev, Banabakova, Georgiev, 2017k, s. 97-100; Terziev, Banabakova, Georgiev, 2017I, s. 107-110; Terziev, Banabakova, Georgiev, 2017m, s. 111-115; Terziev, Banabakova, Georgiev, 2017n, s. 116-120; Terziev, Banabakova, Georgiev, 2017o, s. 120-124; Terziev, Banabakova, Georgiev, 2017p, s. 125-128; Terziev, Banabakova, Georgiev, 2017q, s. 128-131; Terziev, Banabakova, Georgiev, 2017r, s. 131-135; Terziev, Banabakova, Georgiev, 2017s, s. 135-139; Terziev, Banabakova, Georgiev, 2017t, s. 13-16; Terziev, Banabakova, Georgiev, 2017u, s. 16-19; Terziev, Banabakova, Georgiev, 2017v, s. 20-23).

Therefore, the understanding and consideration of these factors for the social activity of the human factor is in the basis of the formation of managers at all levels in the managerial hierarchy of the social system 
(strategic, operational and tactical levels) with established leadership skills on the basis of collective qualification and team work. This means forming ability for:

- Management of change in the social environment by bringing together experts with different backgrounds in the realization of the set objectives;

- Linking the goals with the personal interest;

- Motivating highly efficient communication between the individual experts;

- Merging the collective, the social with the personal responsibility in the tasks execution;

- Optimal use of the skills of the members of the team, corresponding to the nature and complexity of the executed tasks.

\section{CONCLUSION}

Without claiming to be exhaustive, we believe that the application of the model of collective qualification allows the disclosure of the potential of both the individual and the team, and the society as a whole, in achieving the end results, united by the global objective of social management. This, according to the theory of leadership, is the basis of focusing „on the release of human talent and realizing the potential of the people" in managing change in the social system, in public relations, in accordance with the changes in the social environment.

Adaptation of the model of collective qualification and team work allows defining the role and place of the human factor in social management by the dependency "goal-results", which is the basis of management by result and rationalization of managerial decisions (Terziev, Georgiev, Georgiev, 2017w, pp. 295-300; Terziev, Georgiev, Georgiev, 2017x, pp. 300-305; Terziev, Georgiev, Georgiev, 2017y, pp. 305-311; Terziev, Georgiev, Georgiev, 2017z, pp. 311-317; Terziev, Georgiev, Georgiev, 2017aa, pp. 317-324; Terziev, Georgiev, Georgiev, 2017ab, pp. 324-329; Terziev, Georgiev, Georgiev, 2017ac, pp. 329-335; Terziev, Georgiev, 2018, pp. 452-461; Terziev, Georgiev, 2018a, pp. 6-15; Terziev, Banabakova, Stefanov, Georgiev, 2018b, pp. 267-272; Terziev, Banabakova, Stefanov, Georgiev, 2018c, pp. 79-87).

\section{REFERENCE LIST}

Terziev, V., Georgiev, M. (2017). Active social programs development in Bulgaria: Contemporary challenges and social management instruments. // International Journal of Humanities and Social Science Invention. www.ijhssi.org, 6, 2017, N 1, pp. 94-101, ISSN (Online): 2319 - 7722, ISSN (Print): 2319 7714.

Terziev, V., Georgiev, M. (2017a). The active model of a social programme and ITS strategic advantage. // Medical Teacher. Taylor \& Francis, 39, 2017, N 12 (2), pp. 1418-1437, ISSN: 0142-159X (Print), ISSN: 1466-187X (Online).

Terziev, V., Georgiev, M. (2017b). Highlights of the Evolution of the 'Balanced Scorecard' idea as a model for managing strategy development and control. // IJASOS- International E-journal of Advances in Social Sciences, OCERINT International Organization Center Of Academic Research, 3, 2017, N 8, pp. 602606, e-ISSN: 2411-183X.

Terziev, V., Georgiev, M. (2017c). Highlights of the evolution of the 'Balanced Scorecard' idea as a model for managing strategy development and control. // SOCIOINT 2017- 4th International Conference on Education, Social Sciences and Humanities 10-12 July 2017- Dubai, UAE, OCERINT- International Organization Center of Academic Research, 2017, pp. 607-610, ISBN: 978-605-82433-1-6.

Terziev, V., Banabakova, V., Ilsheva, M. Georgiev, M. (2017d). Motivation and stimulation of workers as a basic aspect of the organization. // Scientific journal «Economics and finance». GPG Publishing Group, Pretoria, South Africa, Challenges and opportunities of scientific thought development: Collection of scientific articles, 2017, pp. 44-53, ISBN 978-0-9942661-6-3.

Terziev, V., Banabakova, V., Ilsheva, M., Georgiev, M. (2017e). Controlling as a management function of the organization. // Scientific journal «Economics and finance». GPG Publishing Group, Pretoria, South Africa, Challenges and opportunities of scientific thought development: Collection of scientific articles, 
IJASOS- International E-Journal of Advances in Social Sciences, Vol. IV, Issue 12, December 2018

2017, pp. 138-145, ISBN 978-0-9942661-6-3.

Terziev, V., Banabakova, V., Georgiev, M. (2017f). Razvitie i perestrukturirovanie zanyatosti v Bolgarii s nachala perehoda k raynochnoy ekonomike i v goday evropeyskoy integratsii. // Gromadsyka organizatsiya «Kiïvsykiy ekonomichniy naukoviy tsentr» Zbirnik materialiv vseukraïnsykoï naukovopraktichnoï konferentsiï «Pidpriemnitstvo, buhgaltersykiy oblik ta finansi: natsionalyni osoblivosti ta svitovi tendentsiï» 15-16 veresnya 2017 roku, Kiïv 2017, s.64-69 (Терзиев. В, Банабакова. В., Георгиев, М. Развитие и переструктурирование занятости в Болгарии с начала перехода к рыночной экономике и в годы европейской интеграции. // Громадська організація «Київський економічний науковий центр» Збірник матеріалів всеукраїнської науково-практичної конфреренції «Підприємництво, бухгалтерський облік та фінанси: національні особливості та світові тенденції» 15-16 вересня 2017 року, Київ 2017, с.64-69).

Terziev, V., Banabakova, V., Georgiev, M. (2017g). Razvitie i perestrukturirovanie zanyatosti v Bolgarii. // Gromadsyka organizatsiya «Kiïvsykiy ekonomichniy naukoviy tsentr» Zbirnik materialiv vseukraïnsykoï naukovo-praktichnoï konferentsiï «Pidpriemnitstvo, buhgaltersykiy oblik ta finansi: natsionalyni osoblivosti ta svitovi tendentsiï» 15-16 veresnya 2017 roku, Kiïv 2017, s.70-75 (Терзиев. B, Банабакова. В., Георгиев, М. Развитие и переструктурирование занятости в Болгарии. // Громадська організація «Київський економічний науковий центр» Збірник матеріалів всеукраїнської науково-практичної конфреренції «Підприємництво, бухгалтерський облік та фрінанси: національні особливості та світові тенденції» 15-16 вересня 2017 року, Київ 2017, с.7075).

Terziev, V., Banabakova, V., Georgiev, M. (2017h). Politiki dlya vozdeystviya i analiz sostoyaniya na raynok truda. // Gromadsyka organizatsiya «Kiïvsykiy ekonomichniy naukoviy tsentr» Zbirnik materialiv vseukraïnsykoï naukovo-praktichnoï konferentsiï «Pidpriemnitstvo, buhgaltersykiy oblik ta finansi: natsionalyni osoblivosti ta svitovi tendentsiï» 15-16 veresnya 2017 roku, Kiïv 2017, s.76-81 (Терзиев. В, Банабакова. В., Георгиев, М. Политики для воздействия и анализ состояния на рынок труда. // Громадська організація «Київський економічний науковий центр» Збірник матеріалів всеукраїнської науково-практичної конференції «Підприємництво, бухгалтерський облік та фінанси: національні особливості та світові тенденції» 15-16 вересня 2017 року, Київ 2017. с.7681).

Terziev, V., Banabakova, V., Georgiev, M. (2017i). Razvitie kontseptsii sotsialynoy ekonomiki. // Materiali dopovidey mizhnarodnoï naukovo - praktichnoï konferentsiï «Suchasni mozhlivosti zabezpechennya sotsialyno-ekonomichnogo rozvitku kraïn» 16 veresnya 2017 roku, Ministerstvo osviti i nauki Ukraïni, Uzhgorodsykiy natsionalyniy universitet, Fakulytet mizhnarodnih ekonomichnih vidnosin, Ekonomichniy fakulytet, Institut derzhavnogo upravlinnya ta regionalynogo rozvitku, Uzhgorod, 2017, s. 103-106, ISBN 978-966-916-348-6 (Терзиев. В, Банабакова. В., Георгиев, М. Развитие концепции социальной экономики. // Матеріали доповідей міжнародної науково - практичної конференції «Сучасні можливості забезпечення соціально-економічного розвитку країн» 16 вересня 2017 року, Міністерство освіти і науки України, Ужгородський національний університет, Факультет міжнародних економічних відносин, Економічний факультет, Інститут державного управління та регіонального розвитку, Ужгород, 2017, с. 103-106, ISBN 978-966-916-348-6).

Terziev, V., Banabakova, V., Georgiev, M. (2017j). Osobennosti, institutsii i znachenie razvitiya raynka truda. Materiali dopovidey mizhnarodnoï naukovo - praktichnoï konferentsiï «Suchasni mozhlivosti zabezpechennya sotsialyno-ekonomichnogo rozvitku kraïn» 16 veresnya 2017 roku, Ministerstvo osviti i nauki Ukraïni, Uzhgorodsykiy natsionalyniy universitet, Fakulytet mizhnarodnih ekonomichnih vidnosin, Ekonomichniy fakulytet, Institut derzhavnogo upravlinnya ta regionalynogo rozvitku, Uzhgorod, 2017, s. 100-103, ISBN 978-966-916-348-6 (Терзиев. В, Банабакова. В., Георгиев, М. Особенности, институции и значение развития рынка труда. Матеріали доповідей міжнародної науково - практичної конференції «Сучасні можливості забезпечення соціально-економічного розвитку країн» 16 вересня 2017 року, Міністерство освіти і науки України, Ужгородський національний університет, Факультет міжнародних економічних відносин, Економічний фракультет, Інститут державного управління та регіонального розвитку, Ужгород, 2017, с. 100103, ISBN 978-966-916-348-6).

T Terziev, V., Banabakova, V., Georgiev, M. (2017k). Osobennosti, institutsii i znachenie razvitiya raynka truda dlya dostizheniya ustoychivogo ekonomicheskogo i sotsialynogo razvitiya. // Materiali dopovidey mizhnarodnoï naukovo - praktichnoï konferentsiï «Suchasni mozhlivosti zabezpechennya sotsialynoekonomichnogo rozvitku kraïn» 16 veresnya 2017 roku, Ministerstvo osviti i nauki Ukraïni, Uzhgorodsykiy natsionalyniy universitet, Fakulytet mizhnarodnih ekonomichnih vidnosin, 
Ekonomichniy fakulytet, Institut derzhavnogo upravlinnya ta regionalynogo rozvitku, Uzhgorod, 2017, s. 97-100, ISBN 978-966-916-348-6 (Терзиев. В, Банабакова. В., Георгиев, М. Особенности, институции и значение развития рынка труда для достижения устойчивого экономического и социального развития. // Матеріали доповідей міжнародної науково - практичної конференції «Сучасні можливості забезпечення соціально-економічного розвитку країн» 16 вересня 2017 року, Міністерство освіти і науки України, Ужгородський національний університет, Факультет міжнародних економічних відносин, Економічний фракультет, Інститут державного управління та регіонального розвитку, Ужгород, 2017, с. 97-100, ISBN 978-966-916-348-6).

Terziev, V., Banabakova, V., Georgiev, M. (2017l). Sotsialynaye politiki dlya vozdeystviya na raynok truda i razvitie natsionalynoy kontseptsii sotsialynoy ekonomiki. // Strategichni orientiri rozvitku ekonomiki Ukraïni, Mizhnarodna naukovo-praktichna konferentsiya 6-7 zhovtnya 2017 roku, Ministerstvo osviti i nauki Ukraïni, Odesykiy natsionalyniy universitet imeni I. I. Mechnikova, Institut matematiki, ekonomiki ta mehaniki, Kafedra svitovogo gospodarstva i mizhnarodnih ekonomichnih vidnosin, Odesa, 2017, s. 107-110, ISBN 978-617-7326-24-2 (Терзиев, В., Банабакова, В., Георгиев, М. Социальные политики для воздействия на рынок труда и развитие национальной концепции социальной экономики. // Стратегічні орієнтири розвитку економіки України, Міжнародна науково-практична конференція 6-7 жовтня 2017 року, Міністерство освіти і науки України, Одеський національний університет імені І. І. Мечникова, Інститут математики, економіки та механіки, Кафедра світового господарства і міжнародних економічних відносин, Одеса, 2017, с. 107-110, ISBN 978-617-732624-2).

Terziev, V., Banabakova, V., Georgiev, M. (2017m). Soderzhanie i Sushtnosty Sotsialynoy Politiki. // Strategichni orientiri rozvitku ekonomiki Ukraïni, Mizhnarodna naukovo-praktichna konferentsiya 6-7 zhovtnya 2017 roku, Ministerstvo osviti i nauki Ukraïni, Odesykiy natsionalyniy universitet imeni I. I. Mechnikova, Institut matematiki, ekonomiki ta mehaniki, Kafedra svitovogo gospodarstva i mizhnarodnih ekonomichnih vidnosin, Odesa, 2017, s. 111-115, ISBN 978-617-7326-24-2 (Терзиев, В., Банабакова, В., Георгиев, М. Содержание и Сущность Социальной Политики. // Стратегічні орієнтири розвитку економіки України, Міжнародна науково-практична конференція 6-7 жовтня 2017 року, Міністерство освіти і науки України, Одеський національний університет імені I. І. Мечникова, Інститут математики, економіки та механіки, Кафедра світового господарства і міжнародних економічних відносин, Одеса, 2017, с. 111-115, ISBN 978-617-7326-24-2).

Terziev, V., Banabakova, V., Georgiev, M. (2017n). Problemay zanyatosti i bezrabotitsay. // Strategichni orientiri rozvitku ekonomiki Ukraïni, Mizhnarodna naukovo-praktichna konferentsiya 6-7 zhovtnya 2017 roku, Ministerstvo osviti i nauki Ukraïni, Odesykiy natsionalyniy universitet imeni I. I. Mechnikova, Institut matematiki, ekonomiki ta mehaniki, Kafedra svitovogo gospodarstva i mizhnarodnih ekonomichnih vidnosin, Odesa, 2017, s. 116-120, ISBN 978-617-7326-24-2 (Терзиев, В., Банабакова, В., Георгиев, М. Проблемы занятости и безработицы. // Стратегічні орієнтири розвитку економіки України, Міжнародна науково-практична конференція 6-7 жовтня 2017 року, Міністерство освіти і науки України, Одеський національний університет імені І. І. Мечникова, Інститут математики, економіки та механіки, Кафедра світового господарства і міжнародних економічних відносин, Одеса, 2017, с. 116-120, ISBN 978-617-7326-24-2).

Terziev, V., Banabakova, V., Georgiev, M. (2017o). Razvitie raynka truda v Bolgarii. // Strategichni orientiri rozvitku ekonomiki Ukraïni, Mizhnarodna naukovo-praktichna konferentsiya 6-7 zhovtnya 2017 roku, Ministerstvo osviti i nauki Ukraïni, Odesykiy natsionalyniy universitet imeni I. I. Mechnikova, Institut matematiki, ekonomiki ta mehaniki, Kafedra svitovogo gospodarstva i mizhnarodnih ekonomichnih vidnosin, Odesa, 2017, s. 120-124, ISBN 978-617-7326-24-2 (Терзиев, В., Банабакова, В., Георгиев, М. Развитие рынка труда в Болгарии. // Стратегічні орієнтири розвитку економіки України, Міжнародна науково-практична конференція 6-7 жовтня 2017 року, Міністерство освіти і науки України, Одеський національний університет імені І. І. Мечникова, Інститут математики, економіки та механіки, Кафедра світового господарства і міжнародних економічних відносин, Одеса, 2017, с. 120-124, ISBN 978-617-7326-24-2).

Terziev, V., Banabakova, V., Georgiev, M. (2017p). Razvitie kontseptsii sotsialynoy ekonomiki. // Strategichni orientiri rozvitku ekonomiki Ukraïni, Mizhnarodna naukovo-praktichna konferentsiya 6-7 zhovtnya 2017 roku, Ministerstvo osviti i nauki Ukraïni, Odesykiy natsionalyniy universitet imeni I. I. Mechnikova, Institut matematiki, ekonomiki ta mehaniki, Kafedra svitovogo gospodarstva i mizhnarodnih ekonomichnih vidnosin, Odesa, 2017, s. 125-128, ISBN 978-617-7326-24-2 (Терзиев, В., Банабакова, В., Георгиев, М. Развитие концепции социальной экономики. // Стратегічні орієнтири розвитку економіки України, Міжнародна науково-практична конфреренція 6-7 жовтня 
IJASOS- International E-Journal of Advances in Social Sciences, Vol. IV, Issue 12, December 2018

2017 року, Міністерство освіти і науки України, Одеський національний університет імені І. І. Мечникова, Інститут математики, економіки та механіки, Кафедра світового господарства і міжнародних економічних відносин, Одеса, 2017, с. 125-128, ISBN 978-617-7326-24-2).

Terziev, V., Banabakova, V., Georgiev, M. (2017q). Sotsialynoy ekonomiki i sotsialynogo predprinimatelystva. // Strategichni orientiri rozvitku ekonomiki Ukraïni, Mizhnarodna naukovopraktichna konferentsiya 6-7 zhovtnya 2017 roku, Ministerstvo osviti i nauki Ukraïni, Odesykiy natsionalyniy universitet imeni I. I. Mechnikova, Institut matematiki, ekonomiki ta mehaniki, Kafedra svitovogo gospodarstva i mizhnarodnih ekonomichnih vidnosin, Odesa, 2017, s. 128-131, ISBN 978617-7326-24-2 (Терзиев, В., Банабакова, В., Георгиев, М. Социальной экономики и социального предпринимательства. // Стратегічні орієнтири розвитку економіки України, Міжнародна науковопрактична конференція 6-7 жовтня 2017 року, Міністерство освіти і науки України, Одеський національний університет імені І. І. Мечникова, Інститут математики, економіки та механіки, Кафедра світового господарства і міжнародних економічних відносин, Одеса, 2017, с. 128-131, ISBN 978-617-7326-24-2).

Terziev, V., Banabakova, V., Georgiev, M. (2017r). Sotsialynaya ekonomika i sotsialynoe predpriyatie. // Strategichni orientiri rozvitku ekonomiki Ukraïni, Mizhnarodna naukovo-praktichna konferentsiya 6-7 zhovtnya 2017 roku, Ministerstvo osviti i nauki Ukraïni, Odesykiy natsionalyniy universitet imeni I. I. Mechnikova, Institut matematiki, ekonomiki ta mehaniki, Kafedra svitovogo gospodarstva i mizhnarodnih ekonomichnih vidnosin, Odesa, 2017, s. 131-135, ISBN 978-617-7326-24-2 (Терзиев, В., Банабакова, В., Георгиев, М. Социальная экономика и социальное предприятие. // Стратегічні орієнтири розвитку економіки України, Міжнародна науково-практична конференція 6-7 жовтня 2017 року, Міністерство освіти і науки України, Одеський національний університет імені І. І. Мечникова, Інститут математики, економіки та механіки, Кафедра світового господарства і міжнародних економічних відносин, Одеса, 2017, с. 131-135, ISBN 978-617-732624-2).

Terziev, V., Banabakova, V., Georgiev, M. (2017s). Vliyanie sotsialynoy ekonomiki na zanyatosty. // Strategichni orientiri rozvitku ekonomiki Ukraïni, Mizhnarodna naukovo-praktichna konferentsiya 6-7 zhovtnya 2017 roku, Ministerstvo osviti i nauki Ukraïni, Odesykiy natsionalyniy universitet imeni I. I. Mechnikova, Institut matematiki, ekonomiki ta mehaniki, Kafedra svitovogo gospodarstva i mizhnarodnih ekonomichnih vidnosin, Odesa, 2017, s. 135-139, ISBN 978-617-7326-24-2 (Терзиев, В., Банабакова, В., Георгиев, М. Влияние социальной экономики на занятость. // Стратегічні орієнтири розвитку економіки України, Міжнародна науково-практична конференція 6-7 жовтня 2017 року, Міністерство освіти і науки України, Одеський національний університет імені І. І. Мечникова, Інститут математики, економіки та механіки, Кафедра світового господарства і міжнародних економічних відносин, Одеса, 2017, с. 135-139, ISBN 978-617-7326-24-2).

Terziev, V., Banabakova, V., Georgiev, M. (2017t). Politiki dlya sozdaniya funktsioniruyushtego raynka truda v kontekste strategii dlya ustoychivogo, inteligentnogo i vseohvatayvayushtego rosta. // Naukovopraktichnoï konferentsiï Modernizatsiya ekonomiki ta finansovoï sistemi kraïni: aktualyni problemi ta perspektivi 29-30 veresnya 2017 roku, Ministerstvo osviti i nauki Ukraïni Pridniprovsyka derzhavna akademiya budivnitstva ta arhitekturi Ekonomichniy fakulytet Université du Maine (Frantsiya) Wyższa Szkoła Biznesu - National Louis Uni-versity (Polyshta) Opolysykiy Derzhavniy Universitet (Polyshta) EF, Chastina II, Dnipro, 2017, s. 13-16, ISBN 978-966-916-365-3 (Терзиев, В., Банабакова, В., Георгиев, М. Политики для создания функционирующего рынка труда в контексте стратегии для устойчивого, интелигентного и всеохватывающего роста. // Науково-практичної конференції Модернізація економіки та фрінансової системи країни: актуальні проблеми та перспективи 29-30 вересня 2017 року, Міністерство освіти і науки України Придніпровська державна академія будівництва та архітектури Економічний фракультет Université du Maine (Франція) Wyższa Szkoła Biznesu - National Louis Uni-versity (Польща) Опольський Державний Університет (Польща) ЕФ, Частина II, Дніпро, 2017, с. 13-16, ISBN 978-966-916-365-3).

Terziev, V., Banabakova, V., Georgiev, M. (2017u). Politiki dlya sozdaniya funktsioniruyushtego raynka truda. // Naukovo-praktichnoï konferentsiï Modernizatsiya ekonomiki ta finansovoï sistemi kraïni: aktualyni problemi ta perspektivi 29-30 veresnya 2017 roku, Ministerstvo osviti i nauki Ukraïni Pridniprovsyka derzhavna akademiya budivnitstva ta arhitekturi Ekonomichniy fakulytet Université du Maine (Frantsiya) Wyższa Szkoła Biznesu - National Louis Uni-versity (Polyshta) Opolysykiy Derzhavniy Universitet (Polyshta) EF, Chastina II, Dnipro, 2017, s. 16-19, ISBN 978-966-916-365-3 (Терзиев, В., Банабакова, В., Георгиев, М. Политики для создания фрункционирующего рынка труда. // Науково-практичної конференції Модернізація економіки та фрінансової системи країни: 
актуальні проблеми та перспективи 29-30 вересня 2017 року, Міністерство освіти і науки України Придніпровська державна академія будівництва та архітектури Економічний факультет Université du Maine (Франція) Wyższa Szkoła Biznesu - National Louis Uni-versity (Польща) Опольський Державний Університет (Польща) ЕФ, Частина II, Дніпро, 2017, с. 16-19, ISBN 978966-916-365-3).

Terziev, V., Banabakova, V., Georgiev, M. (2017v). Effektivnoe vliyanie na raynok truda. // Naukovopraktichnoï konferentsiï Modernizatsiya ekonomiki ta finansovoï sistemi kraïni: aktualyni problemi ta perspektivi 29-30 veresnya 2017 roku, Ministerstvo osviti i nauki Ukraïni Pridniprovsyka derzhavna akademiya budivnitstva ta arhitekturi Ekonomichniy fakulytet Université du Maine (Frantsiya) Wyższa Szkoła Biznesu - National Louis Uni-versity (Polyshta) Opolysykiy Derzhavniy Universitet (Polyshta) EF, Chastina II, Dnipro, 2017, s. 20-23, ISBN 978-966-916-365-3 (Терзиев, В., Банабакова, В., Георгиев, М. Эффективное влияние на рынок труда. // Науково-практичної конференції Модернізація економіки та фрінансової системи країни: актуальні проблеми та перспективи 29-30 вересня 2017 року, Міністерство освіти і науки України Придніпровська державна академія будівництва та архітектури Економічний факультет Université du Maine (Франція) Wyższa Szkoła Biznesu - National Louis Uni-versity (Польща) Опольський Державний Університет (Польща) ЕФ, Частина II, Дніпро, 2017, с. 20-23, ISBN 978-966-916-365-3).

Terziev, V., Georgiev, G., Georgiev, M. (2017w). Interpersonal styles for resolving conflicts in the organization. // World scientific extent, Collection of scientific articles Scientific journal «Economics and finance». Agenda Publishing House, United Kingdom, 2017, pp. 295-300, ISBN 978-0-9955865-36.

Terziev, V., Georgiev, G., Georgiev, M. (2017x). Possible solutions for management of stress and conflicts in the organization. // World scientific extent, Collection of scientific articles, Scientific journal «Economics and finance». Agenda Publishing House, United Kingdom, 2017, pp. 300-305, ISBN $978-$ 0-9955865-3-6.

Terziev, V., Georgiev, G., Georgiev, M. (2017y). Occurrence of labor and conflict conflicts in the organization, decisions at a mobbing situation. // World scientific extent, Collection of scientific articles, Scientific journal «Economics and finance». Agenda Publishing House, United Kingdom, 2017, pp. 305-311, ISBN 978-0-9955865-3-6.

Terziev, V., Georgiev, G., Georgiev, M. (2017z). Recognizing mobbing and limitation of its activities in the organization. // World scientific extent, Collection of scientific articles, Scientific journal «Economics and finance». Agenda Publishing House, United Kingdom, 2017, pp. 311-317, ISBN 978-0-9955865-36.

Terziev, V., Georgiev, G., Georgiev, M. (2017aa). Methods for resolving conflicts and managing stress at the workplace. // World scientific extent, Collection of scientific articles, Scientific journal «Economics and finance». Agenda Publishing House, United Kingdom, 2017, pp. 317-324, ISBN 978-0-9955865-3-6.

Terziev, V., Georgiev, G., Georgiev, M. (2017ab). Management styles in the organization. // World scientific extent, Collection of scientific articles, Scientific journal «Economics and finance». Agenda Publishing House, United Kingdom, 2017, pp. 324-329, ISBN 978-0-9955865-3-6.

Terziev, V., Georgiev, G., Georgiev, M. (2017ac). Strategic concept of the company. // World scientific extent, Collection of scientific articles, Scientific journal «Economics and finance». Agenda Publishing House, United Kingdom, 2017, pp. 329-335, ISBN 978-0-9955865-3-6.

Terziev, V., Georgiev, M. (2018). Efficient management as optimization of the organization. // Proceedings of INTCESS2018- 5th International Conference on Education and Social Sciences 5-7 February 2018Istanbul, Turkey, International Organization Center of Academic Research, www.ocerints.org, Istanbul, Turkey, 2018, pp. 452-461, ISBN: 978-605-82433-2-3.

Terziev, V., Georgiev, M. (2018a). Efficient management as optimization of the organization. // IJAEDUInternational E-Journal of Advances in Education, April 2018, International Organization Center of Academic Research, www.ocerints.org, Istanbul, Turkey, 2018, pp. 6-15, 4, 2018, N 10, e-ISSN: 2411183X.

Terziev, V., Banabakova, V., Stefanov, S., Georgiev, M. (2018b). Problems of stimulation of the staff in the conditions of market economy. // Knowledge - International journal scientific papers, promoted in Vrnjacka Banja, Serbia 16-18.03.2018, Institute of Knowledge Management- Skopje, 22, 2018, N 1, pp. 267-272, ISSN 1857-923X (for e - version), ISSN 2545-4439 (for printed version). 
IJASOS- International E-Journal of Advances in Social Sciences, Vol. IV, Issue 12, December 2018

Terziev, V., Banabakova, V., Stefanov, S., Georgiev, M. (2018c). Internal-organizational training as a process for continuing education. // Knowledge - International journal scientific papers, promoted in Vrnjacka Banja, Serbia 16-18.03.2018, Institute of Knowledge Management- Skopje, 22, 2018, N 1, pp. 79-87, ISSN 1857-923X (for e - version), ISSN 2545-4439 (for printed version).

Terziev, V., Banabakova, V., Stefanov. S., Georgiev, M. (2018d). Difficulties in the division of powers between the co-workers. // Knowledge - International journal scientific papers, promoted in Vrnjacka Banja, Serbia 16-18.03.2018, Institute of Knowledge Management- Skopje, 22, 2018, N 2, pp. 553559, ISSN 1857-923X (for e - version), ISSN 2545-4439 (for printed version).

Terziev, V., Banabakova, V., Georgiev, M. (2018e). Modern dimensions of social policies. // International journal scientific papers Vol 23.4 Promoted in Budva, Montenegro 24-27.05.2018, IKM - Skopje, 23, 2017, N 4, pp. 935-944, ISSN 1857-923X (for e-version) ISSN 2545- 4439 (for printed version).

Terziev, V., Banabakova, V., Georgiev, M. (2018f). Social support as part of social policy. // International journal scientific papers Vol 23.4 Promoted in Budva, Montenegro 24-27.05.2018, IKM - Skopje, 23, 2017, N 4, pp. 973-980, ISSN 1857-923X (for e-version) ISSN 2545 - 4439 (for printed version). 